OPEN ACCESS

Edited by:

Giamila Fantuzzi,

University of llinois at Chicago,

United States

Reviewed by:

Maria Pini,

INSERM U955 Institut Mondor de Recherche Biomédicale (IMRB),

France

Kieran G. Meade,

University College Dublin, Ireland

${ }^{*}$ Correspondence:

Shengyi Wang

wangshengyi@caas.cn

Zuoting Yan

yanzuoting@caas.cn

Specialty section:

This article was submitted to

Inflammation,

a section of the journal

Frontiers in Immunology

Received: 04 March 2021

Accepted: 07 May 2021

Published: 28 May 2021

Citation:

Ma X, Li Y, Shen W, Oladejo AO, Yang J, Jiang $W$, Imam $B H, W U X$,

Ding $X$, Yang $Y$, Wang $S$ and Yan $Z$

(2021) LPS Mediates Bovine Endometrial Epithelial Cell Pyroptosis

Directly Through Both NLRP3

Classical and Non-Classical

Inflammasome Pathways.

Front. Immunol. 12:676088.

doi: 10.3389/fimmu.2021.676088

\section{LPS Mediates Bovine Endometrial Epithelial Cell Pyroptosis Directly Through Both NLRP3 Classical and Non-Classical Inflammasome Pathways}

\author{
Xiaoyu Ma ${ }^{1,2}$, Yajuan $\mathrm{Li}^{1}$, Wenxiang Shen ${ }^{1}$, Ayodele Olaolu Oladejo ${ }^{1,3}$, Jie Yang ${ }^{1}$, \\ Wei Jiang ${ }^{1}$, Bereket Habte Imam ${ }^{1}$, Xiaohu Wu ${ }^{1}$, Xuezhi Ding ${ }^{1}$, Ying Yang ${ }^{2}$, \\ Shengyi Wang ${ }^{1 *}$ and Zuoting Yan ${ }^{1 *}$ \\ 1 Key Laboratory of Veterinary Pharmaceutical Development, Ministry of Agricultural and Rural Affairs, Lanzhou Institute of \\ Husbandry and Pharmaceutical Science, Chinese Academy of Agricultural Science, Lanzhou, China, ${ }^{2}$ College of Veterinary \\ Medicine, Inner Mongolia Agricultural University, Hohhot, China, ${ }^{3}$ Department of Animal Health Technology, Oyo State \\ College of Agriculture and Technology, Igboora, Nigeria
}

As a highly inflammatory form of programmed cell death, pyroptosis is triggered by proinflammatory signals and associated with inflammation. It is characterized by cell swelling and large bubbles emerging from the plasma membrane, which release cytokines during inflammation. Compared with other types of cell death, pyroptosis has a distinct morphology and mechanism and involves special inflammasome cascade pathways. However, the inflammasome mechanism through which endometrial epithelial cell pyroptosis occurs in LPS-mediated inflammation remains unclear. We confirmed that there was an increased mRNA and protein expression of the IL-6, TNF- $\alpha, I L-1 \beta, I L-18$ cytokines, the inflammasome molecules NLRP3, CASPASE-1, CASPASE-4, and GSDMD in LPSinduced primary bovine endometrial epithelial cells (BEECs) in an in vitro established inflammatory model using ELISA, real-time PCR (RT-PCR), vector construction and transfection, and Western blotting. Scanning electron microscopy and lactate dehydrogenase $(\mathrm{LDH})$ activity assays revealed induced cell membrane rupture, which is the main characteristic of pyroptosis. In conclusion, the cytolytic substrate GSDMD's cleavage by caspase-1 or caspase-4 through the NLRP3 classical and non-classical inflammasome pathways, GSDMD N-terminus bind to the plasma membrane to form pores and release IL -18, IL-1 $\beta$ cause cell death during LPS induced BEECs inflammation.

Keywords: BEEC, LPS, inflammasome, GSDMD, pyroptosis

\section{INTRODUCTION}

The uterus is the organ for embryonic development and the supply of fetal nutrition through the fetomaternal interactions. It is also an organ with a complex immune repertoire. The complete tissue structure and healthy function of the uterus are the basis of maternal reproduction. Almost all cows' reproductive systems will be infected with bacteria after parturition $(1,2)$. The inflammatory 
environment is increased in the bovine uterus due to bacterial contamination and tissue degradation driven by local pathogenassociated molecular patterns (PAMPs) and damage-associated molecular patterns (DAMPs). Post-parturition inflammation has been described as a normal physiological event, indicating that the bovine uterus needs proper tissue remodeling to restore its homeostasis for future pregnancy $(3,4)$. Although, most cows try to eliminate bacterial contamination in the uterus during post parturient through the uterine mucosal immune response, about half of postpartum cows still develop endometritis (5), which has a high incidence of disease in postpartum cows worldwide. Reports have shown that clinical endometritis occurs in more than $40 \%$ of cows within first three weeks postpartum (6), with its $67 \%$ occurring in Europe and North America (7). Research evidences have shown that high-yield cows have more susceptible to the disease than low-yield cows (8). Cow endometritis induces uterine tissue damage, embryonic death, a prolonged luteal phase, and increased fetal distance, infertility, and fetal death $(9,10)$, and directly reduces the economic value of dairy cows, retards the dairy cattle breeding development, which causes great harm to postpartum dairy cows' health recovery and serious losses in the dairy industry. Some cattle also develop sub-clinical endometritis partially due to persistent uterine infection $(11,12)$, making it even more difficult to cure and resulting in a higher economic loss (13).

Pathogenic microorganisms, such as bacteria, play an important role in the pathogenesis of endometritis in dairy cows, including the Escherichia coli, Trueprella pyogenes, Prevotella species, and Streptococcus pyogenes. E. coli and S. pyogenes are the most widespread pathogens, and the uterus is most susceptible to $E$. coli infection (14-16). Etiological studies have shown that infection of the female genital tract by Gram-negative bacteria is one of the most important causes of infertility, early abortion, and uterine infection. The lipopolysaccharide (LPS) endotoxin, a PAMP produced by Gram-negative bacteria, is the fundamental factor that triggers the immune response associated with endometritis (17-19).

Pyroptosis, a type of inflammatory necrosis, is a highly inflammatory form of programmed cell death (20), characterized by cell swelling and large bubbles emerging from the plasma membrane $(21,22)$. Pyroptosis has a distinct morphology and mechanism as compared to other types of cell death (23-25). Caspase-1, an interleukin-1 converting enzyme, proteolytically cleaves the precursors of the inflammatory cytokines, such as IL-1 $\beta$ and IL-18, as well as the pyroptosis inducer gasdermin D (GSDMD) (26) to trigger pyroptosis via the classical inflammasome pathway $(27,28)$. Pro-caspase-1 can be recruited and activated within inflammasomes following its assembly (29). Other studies have shown that another means of mediating pyroptosis, caspase-11 in mice, or caspase-4/5 in humans, can serve as direct receptors for LPS. After binding with LPS, it cleaves GSDMD directly, leading to pyroptosis via the non-classical inflammasome pathway (30-32). NACHT, leucine-rich repeat sequence (LRR), and PYRIN-PAADDAPIN (PYD) domains-containing protein 3 (NLRP3), also known as NALP3 and cryopyrin, belongs to the NOD-like receptor (NLR) family, together with the adaptor apoptosis-associated speck-like protein containing CARD (ASC) protein, and PYDCARD, composed of the N-terminal PYD domain protein and a $\mathrm{C}$ - terminal caspase-recruitment domain (CARD) protein, form the caspase- 1 activating complex known as the NLRP3 inflammasome (26). Increasing evidence indicates that the NLRP3 inflammasome, the most characterized and studied inflammasome, responds to various activators, such as microorganisms and their derived products, and endogenous danger signals $(29,33,34)$.

Research on pyroptosis appeared early, but pyroptosis has often confused with apoptosis. The mechanism by which inflammasome mediates pyroptosis was found in the Shao Feng laboratory and the Vishva Dixit laboratory in 2015 (23, 24). Their research showed that cell pyroptosis was caused by the cleavage of GSDMD protein, causing its N-terminal part to oligomerize on the cell membrane and trigger pores, causing the cell membrane to rupture.

Pyroptosis induced by the inflammasome pathways could be one of the molecular mechanisms in dairy cow endometritis pathogenesis. Therefore, this study aims to investigate which inflammasome (classical or non-classical) pathway, or both, plays a role in molecular cell death during endometritis. We hypothesized that pyroptosis in bovine endometritis could occur through the NLRP3 classical or non-classical inflammasome pathways or both.

\section{MATERIALS AND METHODS}

\section{Reagents and Antibodies}

Dulbecco's Modified Eagle Medium (DMEM, high glucose) and phosphate buffer solution (PBS) were purchased from Hyclone (Logan, Utah, USA). Fetal bovine serum (FBS) was purchased from Gibco (Grand Island, USA). Trypsin and Lipopolysaccharide (LPS, E. coli O111: B4) were purchased from Sigma (USA). The LDH assay kit was purchased from Nanjing Jiancheng Bioengineering Institute (Nanjing, China). Bovine IL-6, IL- $1 \beta$, and TNF- $\alpha$ ELISA Kits and the $2.5 \%$ glutaraldehyde (EM Grade), were purchased from Solarbio (Beijing, China). TRIzol ${ }^{\mathrm{TM}}$ Reagent was purchased from Invitrogen (Carlsbad, California, USA). The Evo M-MLV RT-PCR Kit and SYBR ${ }^{\circledR}$ Green Premix Pro Taq HS qPCR Kit were purchased from Accurate Biotechnology (Hunan, China). The ProteinExt ${ }^{\circledR}$ Mammalian Total Protein Extraction Kit was purchased from TransGen Biotech (Beijing, China). The BCA Protein Assay kit was purchased from Takara (Dalian, China). Rabbit anti-bovine NLRP3 antibody (19771-1-AP), rabbit anti-bovine ASC antibody (10500-1AP), and rabbit anti-bovine caspase-1 antibody (22915-1-AP) were purchased from Protein Tech Group (Chicago, USA). Rabbit antibovine caspase-4 antibody (GTX86890) was purchased from Gene Tex (Southern California, USA). Anti-beta actin antibody (ab8226) and Anti-HA tag antibody (ab9110) were purchased from Abcam (Cambridge, MA, USA). Odyssey ${ }^{\circledR}$ Blocking Buffer (TBS), IRDye ${ }^{\circledR}$ $800 \mathrm{CW}$ goat anti-mouse IgG, and IRDye ${ }^{\circledR} 680 \mathrm{RD}$ goat anti-rabbit IgG were purchased from LI-COR (Lincoln City, Nebraska, USA). The pCMV-GSDMD-HA vector was constructed by Genecreate Biological (Wuhan, China), LB Broth and LB Nutrient Agar were purchased from Hope Bio-Technology (Qingdao, China), Ampicillin sodium was purchased from Sangon Biotech (Shanghai, China), and Endo-free Plasmid Mini Kit I was purchased from Omega (USA). Zeta Transfection Kit was purchased from Zeta Life (USA). 


\section{Cell Culture}

Bovine endometrial epithelial cells (BEECs) were isolated from a healthy uterus of a six-month-old dairy cow by our laboratory (35) and were cultured in DMEM supplemented with 10\% FBS at $37^{\circ} \mathrm{C}$ in a humidified atmosphere with $5 \% \mathrm{CO}_{2}$. LPS $(1 \mathrm{mg})$ was diluted into $0,3,10$, and $30 \mu \mathrm{g} / \mathrm{ml}$ by DMEM without FBS. The cell concentration was adjusted to $2 \times 10^{5} / \mathrm{ml}$, and the cells were cultured in the 6-well plate for $24 \mathrm{~h}$; the supernatant was then exchanged replaced with new DMEM containing different concentrations of LPS and 10\% FBS, and cultured for an additional $24 \mathrm{~h}$. Each group was conducted in triplicates.

\section{LDH Assay and Cytokine Detection}

Cultured the BEECs normally and adjusted the density to $2 \times 10^{5}$ / $\mathrm{ml}$. Then transferred cells to the 6 -well plate and incubated at $37^{\circ} \mathrm{C}$ with $5 \% \mathrm{CO}_{2}$ for $24 \mathrm{~h}$. After exposure with different concentrations of LPS for $24 \mathrm{~h}$, and each concentration repeated three times, took out the 6-well plate from the incubator, then the extracellular fluid of each group was collected and centrifuged as required for the kits, and the supernatant was used for the LDH activity assay and cytokine content (IL-6, IL-1 $\beta$, and TNF- $\alpha$ ) analysis via ELISA.

\section{Scanning Electron Microscopy}

The BEECs was reactivated and adjusted the density to $2 \times 10^{5} / \mathrm{ml}$, transferred cells to the 6 -well plate, which contains a $25 \mathrm{~mm}^{2}$ cell slide in each well, and incubated at $37^{\circ} \mathrm{C}$ with $5 \% \mathrm{CO}_{2}$ for $24 \mathrm{~h}$. The cells were observed to grow normally on the slides under an inverted microscope. After exposure to different concentrations of LPS for $24 \mathrm{~h}$ in the incubator, the cultured cells were taken out and washed twice with $2 \mathrm{ml} \mathrm{PBS}$, then added $3 \mathrm{ml} 2.5 \%$ glutaraldehyde, and incubated at room temperature for 1 hour then stored at $4^{\circ} \mathrm{C}$. This was followed up by processing, scanning electron microscope observation and photographing (Lilai Biotechnology Company, Chengdu, China).

\section{Quantitative Real-Time PCR}

Total RNA from the experimented cells was extracted using TRIzol ${ }^{\mathrm{TM}}$ Reagent and quantified using a Nanodrop spectrophotometer (Pultton P100+ type) and RNA gel electrophoresis (Supplemental Table 1 and Figure 1). cDNA was produced by reverse-transcribing the isolated total RNA using an Evo M-MLV RT for PCR Kit and Biometra TOne 96 G PCR machine (Biometra GmbH). The primers are presented in Supplemental Table 2. The qPCR was analyzed using the SYBR ${ }^{\circledR}$ Green Premix Pro Taq HS qPCR Kit, and the gene expression levels were measured by reverse transcription and RTqPCR (Quantstudio ${ }^{\text {TM }} 5$ Real-Time PCR system, Applied Biosystems, Singapore) and quantified using the $2^{-\Delta \Delta \mathrm{Ct}}$ method (36). Three technical replicates were used for all reactions.

\section{Western Blotting}

Total proteins were extracted using the ProteinExt ${ }^{\circledR}$ Mammalian Total Protein Extraction Kit and quantified with the BCA Protein Assay Kit and a Multiskan ${ }^{\mathrm{TM}}$ GO Full-wavelength microplate reader (Thermo Fisher Scientific) at a wavelength of $562 \mathrm{~nm}$. The protein concentration of each group was adjusted with sterile water according to the results of the BCA assay, $6 \times$ Loading Buffer was added and then placed in a metal bath at $100^{\circ} \mathrm{C}$ for $5-15 \mathrm{~min}$ to denature the protein. Separated via $10 \%$ sodium dodecyl sulfate-polyacrylamide gel electrophoresis (SDS-PAGE), then transferred onto NC membranes. Odyssey ${ }^{\circledR}$ Blocking Buffer (TBS) was added and samples were incubated $1 \mathrm{~h}$ at room temperature, then incubated with primary antibodies overnight at $4^{\circ} \mathrm{C}$. The membranes were washed and then incubated with secondary antibodies for $2 \mathrm{~h}$ at room temperature, and then washed again, and the target bands were visualized using the Odyssey ${ }^{\circledR}$ CLx Imaging System (LI-COR, USA).

\section{Genetic Recombination}

Genetic Recombination Technology was adopted to ligate bovine GSDMD DNA fragments into the ampicillin-resistant pCMV-HA vector and transform it into E. coli. Briefly, the bacteria were grown on an LB agar medium containing ampicillin sodium for $24 \mathrm{~h}$ at $37^{\circ} \mathrm{C}$. A single colony was picked and added to the LB liquid medium containing ampicillin sodium and cultured for $16 \mathrm{~h}$ at $37^{\circ} \mathrm{C}$ with shaking at $300 \times g$. Plasmid DNA was extracted with an Endofree Plasmid Mini Kit I and quantified using a Polluton100+. The Zeta Transfection Kit was used to transfect the plasmid into BEECs, and LPS was used to construct the cell inflammation model. The cell total protein was extracted and detected by an HA tag and Western blotting to evaluate the GSDMD protein expression and its cleavage
A

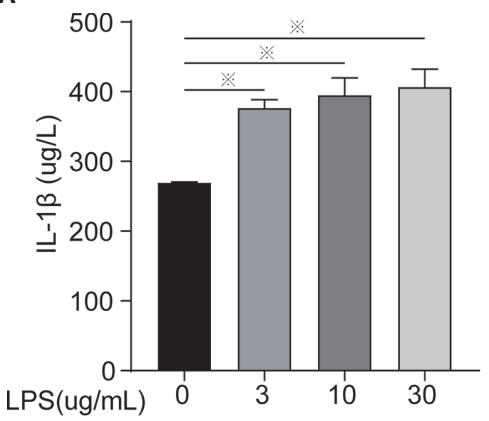

B

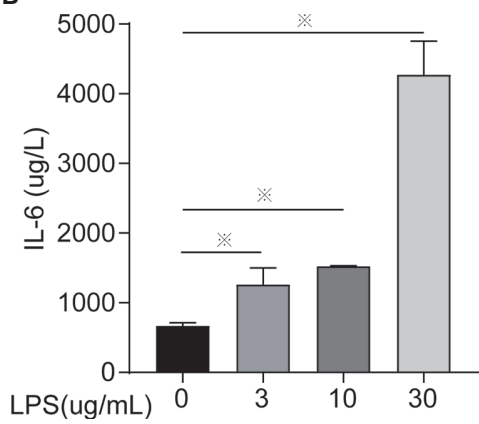

C

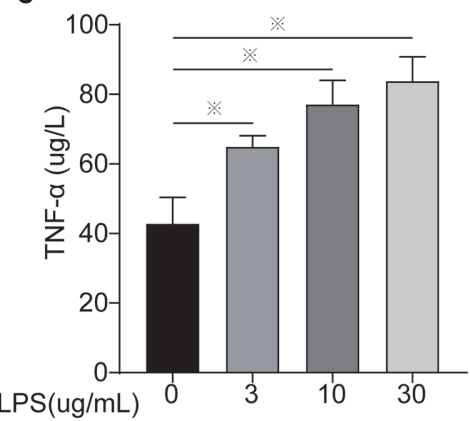

FIGURE 1 | Inflammatory cytokines content of cells treated with different concentrations of LPS for 24 h. (A) IL-1 $\beta$, (B) IL-6, and (C) TNF- $\alpha$. Each treatment had three samples $(\mathrm{n}=3)$ and was repeated three times to reduce system errors; "※” means there was a significant difference $(P<0.05)$ compared with negative control (LPS, $0 \mu \mathrm{g} / \mathrm{ml})$. 
during cell pyroptosis. The vector construction, restriction endonuclease cleavage verification, and sequencing verification were done by Genecreate Biological Company (Wuhan, China).

\section{Statistical Analysis}

The data were analyzed using the SPSS 20.0 software (IBM). Normally distributed data from different groups were compared by one-way ANOVA with $P<0.05$ being considered statistically significant. Graph Pad 8 software (GraphPad Prism San Diego, CA, USA), Adobe Photoshop 2021, and Adobe Illustrator 2019 were used for image creation.

\section{RESULTS}

\section{LPS Induced BEEC Inflammatory Response}

Inflammatory factors (IL-6, IL-1 $\beta$, TNF- $\alpha$, IL-18, and IL-10) were measured to identify the degree of cell inflammation (Figures 1 and 2). After LPS exposure for $24 \mathrm{~h}$, the treated groups (LPS, 3, 10, $30 \mu \mathrm{g} / \mathrm{ml}$ ) had significantly increased IL-6, IL-1 $\beta$, and TNF- $\alpha$ contents in the extracellular fluid (Figure 1) and mRNA expression (Figures 2A-C), compared to controls (LPS, $0 \mu \mathrm{g} / \mathrm{ml}$ ). Only the $30 \mu \mathrm{g} / \mathrm{ml}$ group had significant IL18 mRNA expression (Figure 2D). No statistically significant difference was seen for IL10 mRNA expression among treatments (Figure 2E).
LPS Induced BEEC Cell Membrane Rupture

Morphological changes of cells were analyzed using scanning electron microscopy after $24 \mathrm{~h}$ of LPS exposure. In the control group, the morphology was normal and the cell membrane was intact. The cell morphology of the $3 \mu \mathrm{g} / \mathrm{ml}$ group was still normal, whereas the cell membrane was ruptured in the 10 $\mu \mathrm{g} \mathrm{ml}$ group. In the $30 \mu \mathrm{g} / \mathrm{ml}$ group the cell shape was unclear because the cell membrane was largely damaged, suggesting cell death (Figure 3A). LDH activity was measured to evaluate cell mortality (Figure 3B). After LPS exposure for $24 \mathrm{~h}$, the treated groups (LPS, 3, 10, $30 \mu \mathrm{g} / \mathrm{ml}$ ) had significantly increase LDH activity compared to controls (LPS, $0 \mu \mathrm{g} / \mathrm{ml}$ ), leading to higher cell mortality via cell membrane rupture.

\section{LPS Exposure for $24 \mathrm{~h}$ Leads to BEEC Inflammation via Inflammasomes}

Inflammasomes and GSDMD mRNA and protein expression level were determined to identify whether LPS leads to inflammation via the classical or non-classical inflammasome pathways and/or the occurrence of cellular pyroptosis is mediated through GSDMD. After LPS exposure for $24 \mathrm{~h}$, the 10 and $30 \mu \mathrm{g} / \mathrm{ml}$ treatments significantly increased the mRNA expression of NLRP3, Caspase-1, Caspase-4, and GSDMD (Figures 4A, C-E) and the protein expression of caspase-1 and caspase-4 (Figures 5C, D) compared
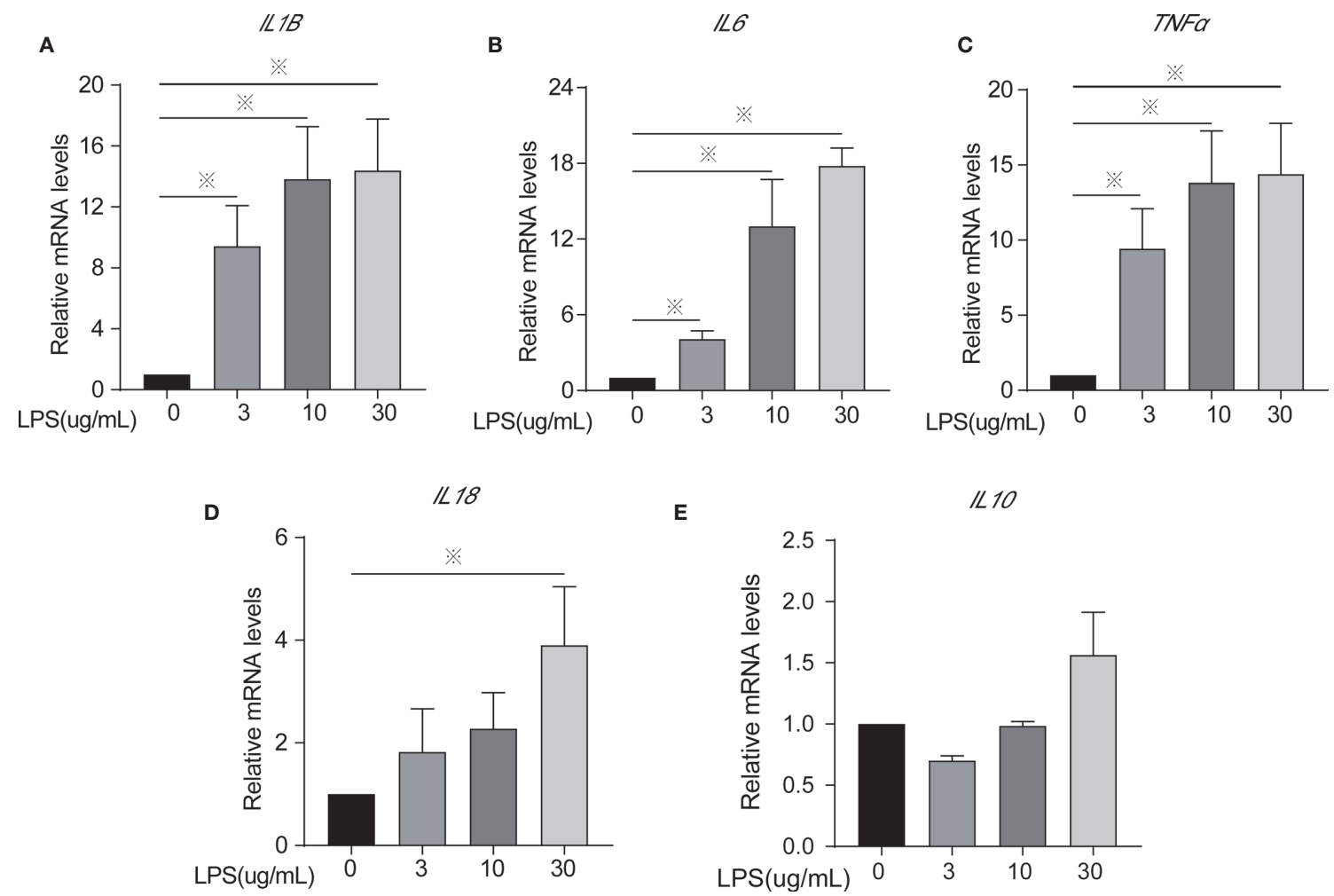

FIGURE 2 | Inflammatory cytokines mRNA expression of cells treated with different concentrations of LPS for 24 h. (A) IL1 $\beta$, (B) IL6, (C) TNF $\alpha$, (D) IL18, and (E) $I L 10$. Each treatment had three samples $(n=3)$ and was repeated three times to reduce system errors; "※” means there was a significant difference $(P<0.05)$ compared with negative control (LPS, $0 \mu \mathrm{g} / \mathrm{ml})$. 
A

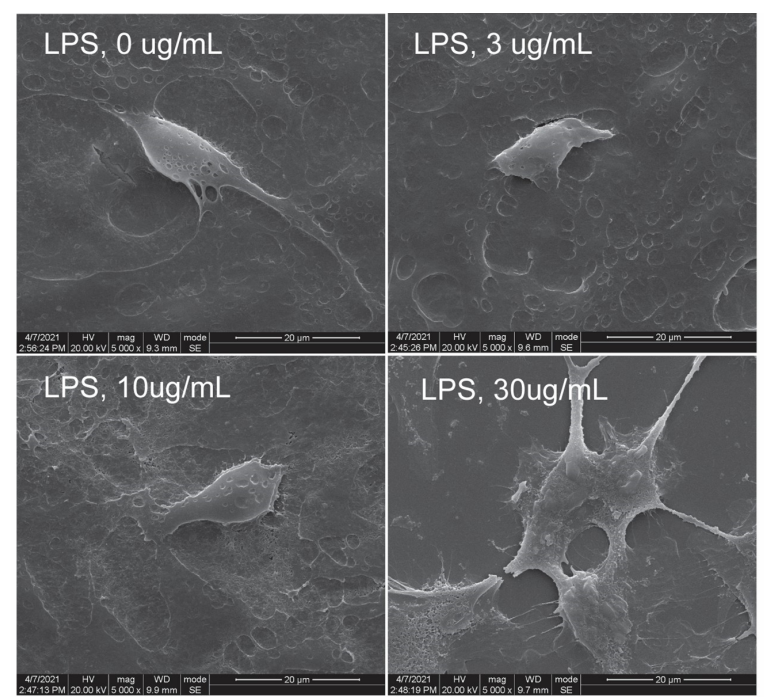

B

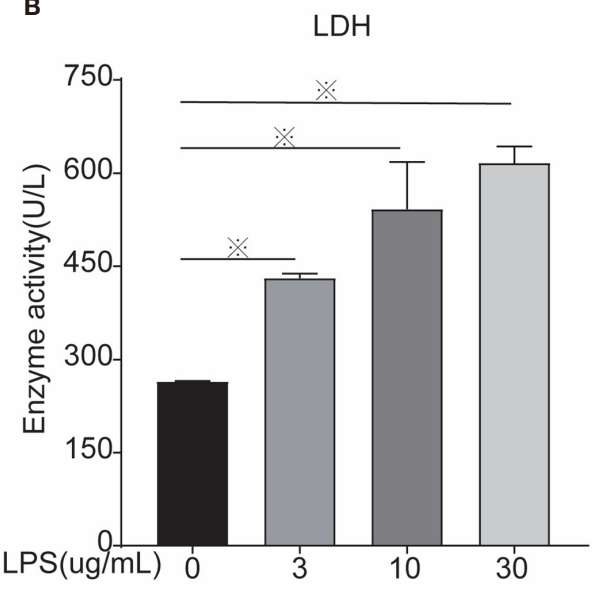

FIGURE 3 | Scanning Electron Microscopy and LDH activity of cells treated with different concentrations of LPS for $24 \mathrm{~h}$. (A) Scanning electron microscopy, and (B) LDH. Each treatment had three samples $(n=3)$ and was repeated three times to reduce system errors; " $*$ " means there was a significant difference $(P<0.05)$ compared with negative control (LPS, $0 \mu \mathrm{g} / \mathrm{mll}$ ); scanning electron microscopy photographing magnification is 5,000 times, and the picture scale was 20 um.
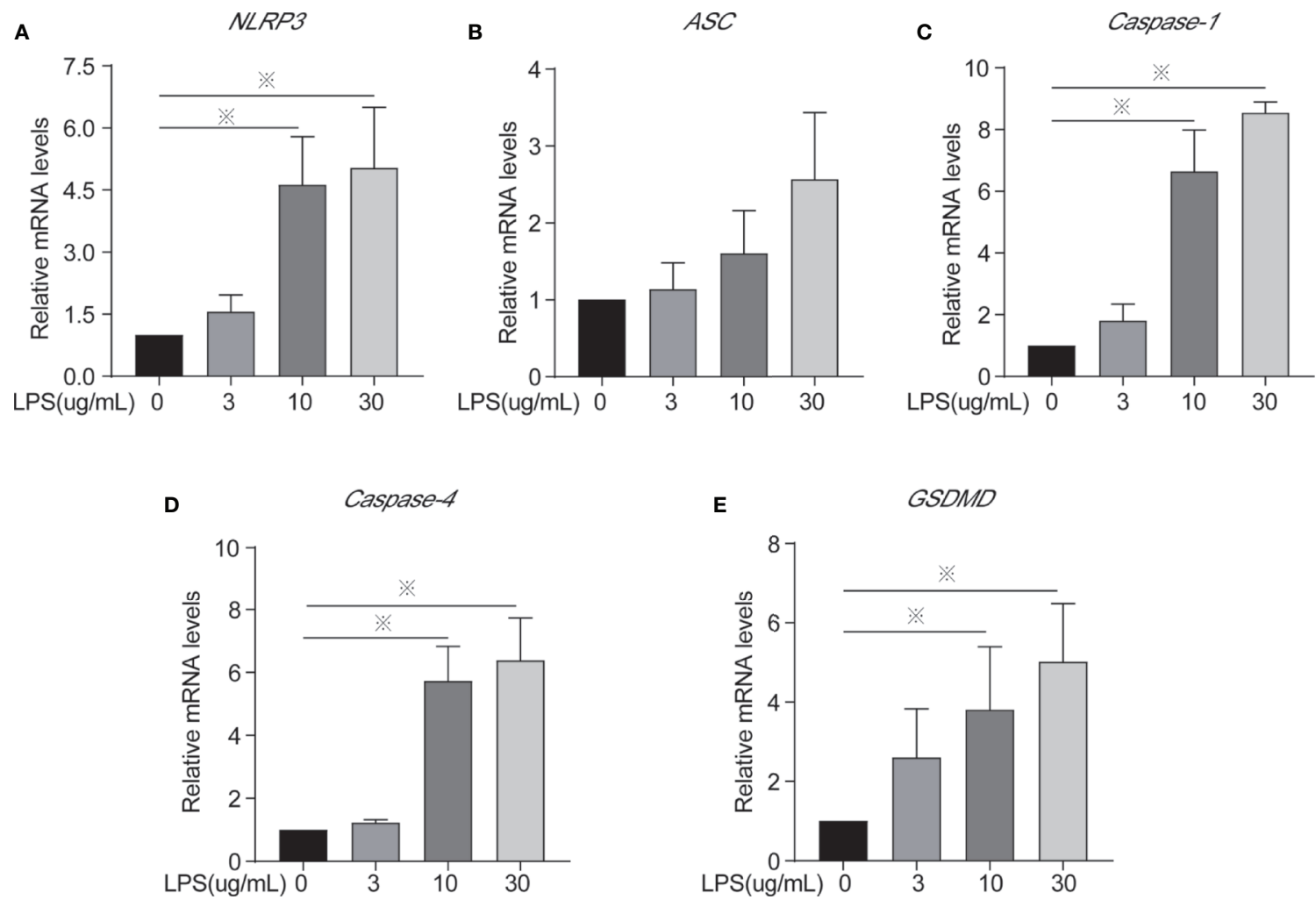

FIGURE 4 | Inflammasomes mRNA expression of cells treated with different concentrations of LPS for 24 h. (A) NLRP3, (B) ASC, (C) Caspase-1, (D) Caspase-4, and $(\mathbf{E})$ GSDMD. Each treatment had three samples $(n=3)$ and was repeated three times to reduce system errors; "※” means there was a significant difference $(P<0.05)$ compared with negative control (LPS, $0 \mu \mathrm{g} / \mathrm{ml})$. 


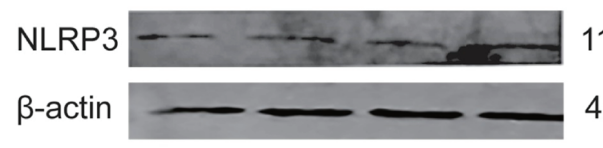

$110 \mathrm{KD}$

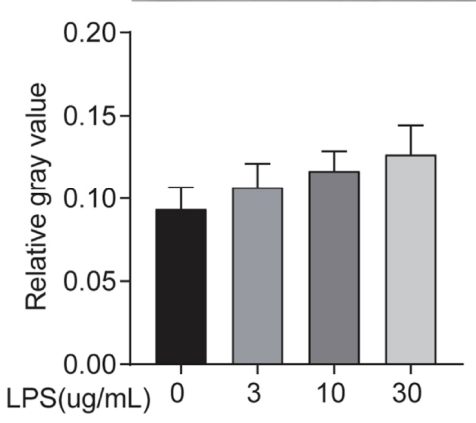

C
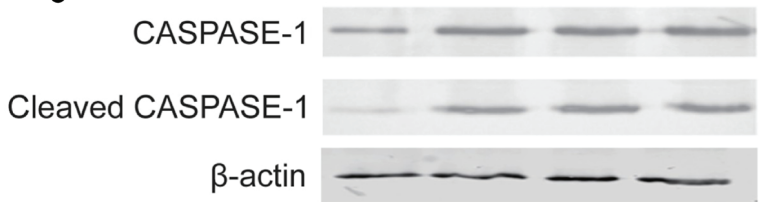

$20 \mathrm{KD}$

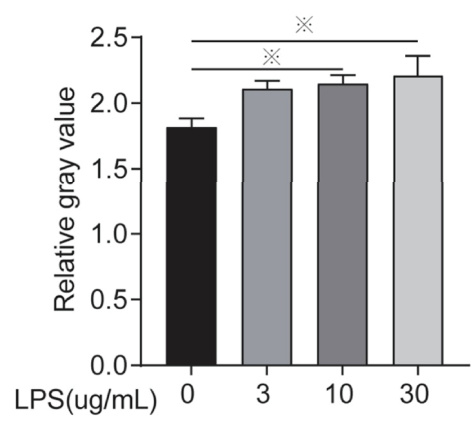

$45 \mathrm{KD}$

42 KD
B
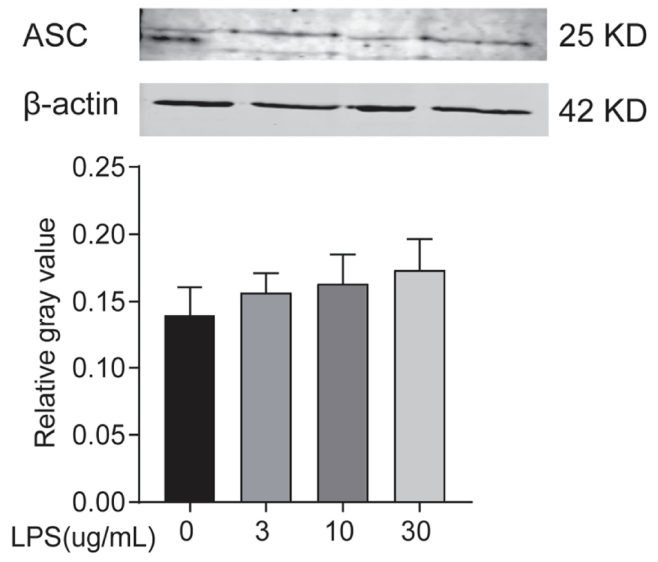

D
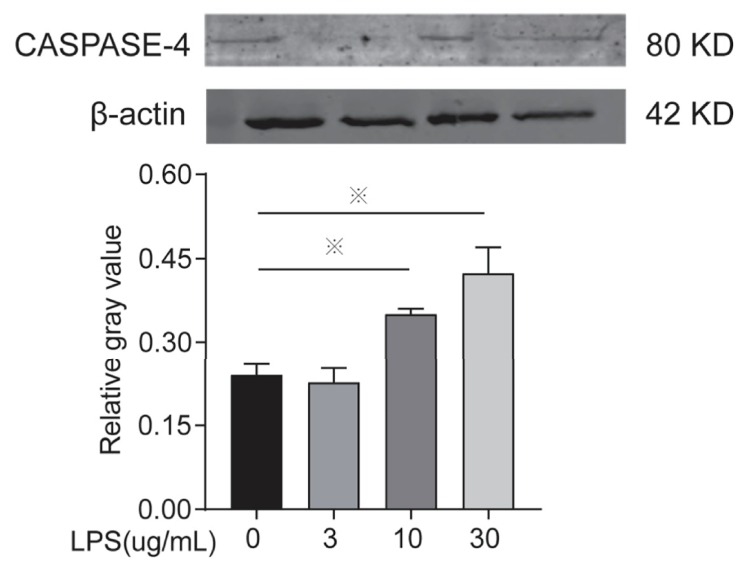

FIGURE 5 | Inflammasomes protein expression of cells treated with different concentrations of LPS for 24 h. (A) Protein electrophoresis, (B) NLRP3, (C) ASC, (D) CASPASE-1, and (E) CASPASE-4. Each treatment had three samples $(n=3)$ and was repeated three times to reduce system errors; "※” means there was a significant difference $(P<0.05)$ compared with negative control $(\mathrm{LPS}, 0 \mu \mathrm{g} / \mathrm{ml})$.

to controls. The mRNA expression of $A S C$, and the protein expression of NLRP3 and ASC showed no statistically significant differences among the groups (Figures $\mathbf{4 B}$ and $\mathbf{5 A}, \mathbf{B}$ ). Cleaved caspase-1 protein could be observed (Figure 5C). The data suggest that LPS exposure for $24 \mathrm{~h}$ leads to BEEC inflammation via classical and non-classical inflammasome pathways.

\section{LPS Exposure for $24 \mathrm{~h}$ Leads to BEEC Inflammation and Cleaved GSDMD to Pyroptosis}

We constructed a pCMV-GSDMD-N-HA vector (Figure 6A) and transfected it to BEECs to overexpress GSDMD, and detected protein expression with Western blotting after $48 \mathrm{~h}$ to ensure the transfection was successful (Figure 6B). The cell inflammation model was rebuilt, total protein was extracted, and GSDMD expression and its cleaved N terminal protein were detected using Western blotting. The results showed that BEEC exposed to LPS ( 10 and $30 \mu \mathrm{g} / \mathrm{ml}$ ) for $24 \mathrm{~h}$ could cleave GSDMD and lead to pyroptosis (Figure 6C).

\section{DISCUSSION}

The endometrium is the first line of defense for the uterus to prevent infection. When pathogenic bacteria invade during postpartum, the epithelial cells activate the innate immune functions, such as the secretion of antibacterial peptides, acute phase proteins, and Tolllike receptor-related functions. When endometrial inflammation occurs, it significantly affects the reproductive function of the uterus (37-39). Therefore, maintaining the proper functioning of endometrial epithelial cells and a complete endometrial gland plays a crucial role in preventing infection and ensuring an excellent reproductive function. The adoption cell models to study the molecular pathological mechanism BEECs during 

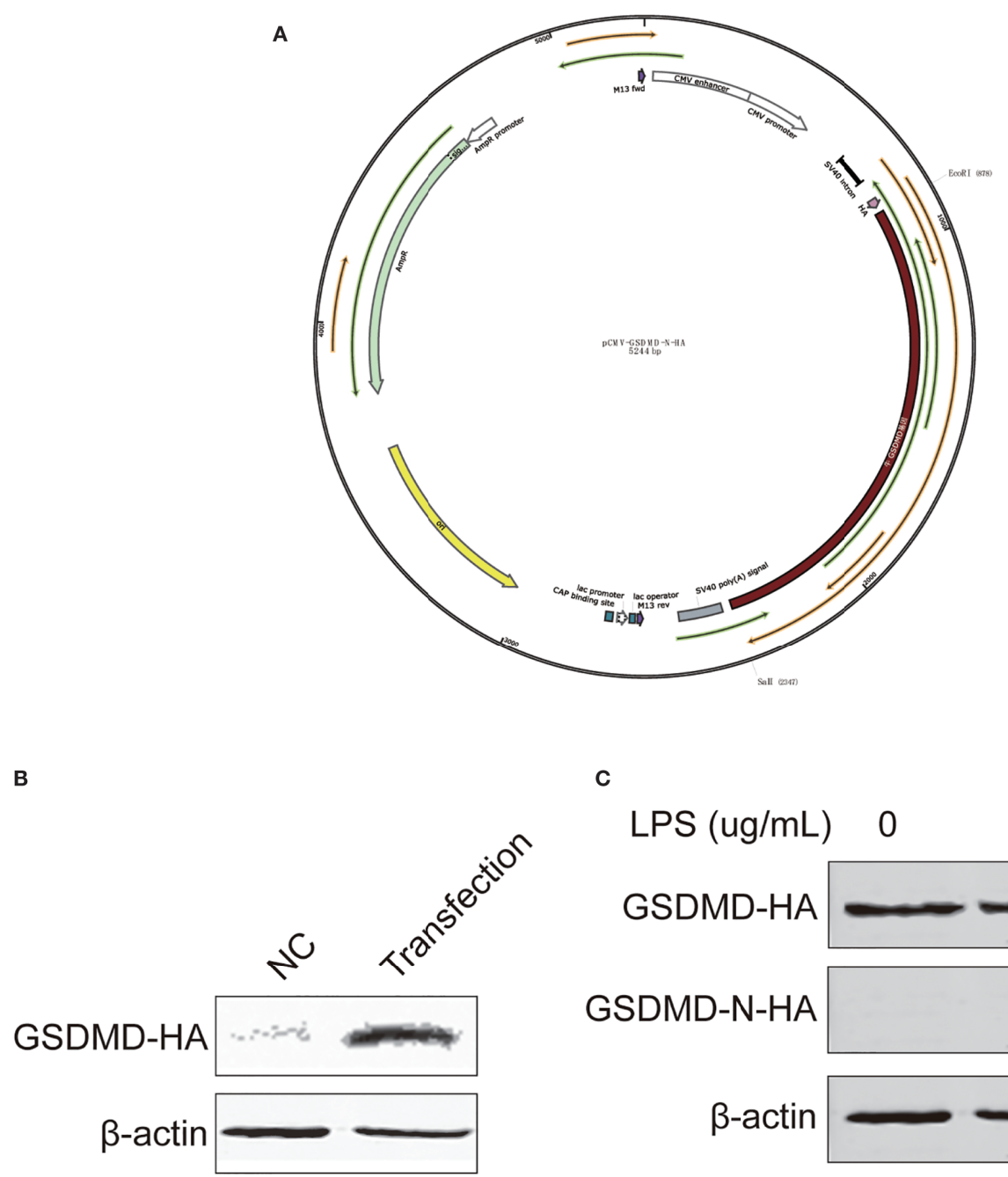

C

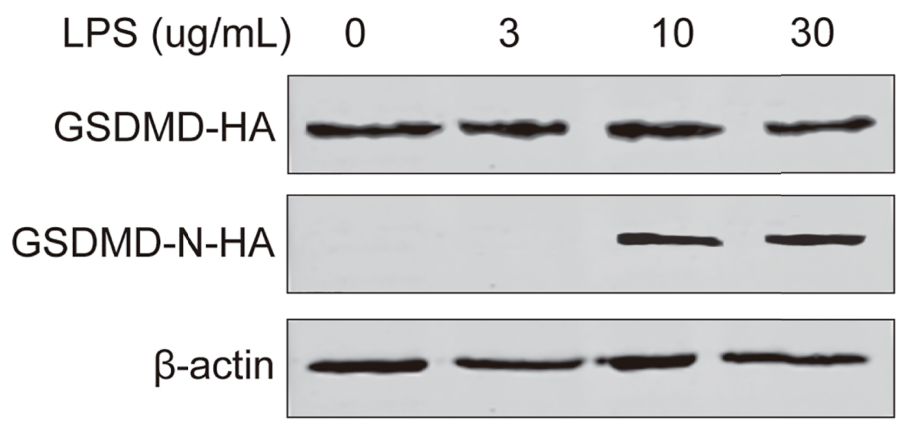

FIGURE 6 | Vector construction, transfection. GSDMD and cleaved N-terminal protein expression of cells treated with different concentrations of LPS for $24 \mathrm{~h}$. (A) the vector, (B) vector transfection, and (C) GSDMD and cleaved N-terminal. Each treatment had three samples $(n=3)$ and was repeated three times to reduce system errors.

inflammation can contribute to the further understanding, prevention, and treatment of cow endometritis.

TNF- $\alpha$, IL- $1 \beta$, and IL- 6 are some of the pro-inflammatory cytokines, which play an important role in the inflammatory response during infectious process (38). TNF- $\alpha$ can initiates cytokine cascades, increased the expression of adhesion factors and vascular permeability $(40,41)$. IL- $1 \beta$ regulates and activates dendritic cells, macrophages, and neutrophils, which are important for enhancing inflammatory response (42). IL-6 regulates immune responses and acute phase responses and is involved in the anti-infective immune response (43). LPS is widely used to construct models and research into acute lung injury, mastitis, and endometritis (44-46). We used different concentrations of LPS to act on BEECs for $24 \mathrm{~h}$ to construct a model of cell inflammation. The levels of TNF- $\alpha$, IL- $1 \beta$, and IL-6 cellular secretion and cellular expression of TNF $\alpha, I L 1 B$, and IL6
mRNA were significantly increased, indicating that the model was successfully constructed. $\mathrm{LDH}$ is an enzyme that exists in cells. Only little is secreted when the cell membrane is intact, but it will be released outside of cells in large amounts if the cell membrane is ruptured. Therefore, $\mathrm{LDH}$ is a sign of the integrity of the cell membrane, and LDH content is often used to measure cell mortality and cell membrane integrity $(47,48)$. The scanning electron microscope is a common technique for observing the surface structure of objects, and it is also used to observe the pores in the cell membrane during pyroptosis (25). Our results suggest that cell death may occur via the rupture of the cell membrane, a hallmark of pyroptosis.

NLRP3 is a member of the NLR family, and it can receive external stimuli through its C-terminal LRR and combine with the PYD domain of ASC through its N-terminal PYD domain. Then, the protein complex can recruit pro-caspase- 1 through the 
CARD domain of ASC to combine with the CARD domain of pro-caspase-1 and leads pro-caspase-1 to mature by selfcleavage. Then, inflammasome immune complexes are formed and can convert cytokines (e.g., IL-18 and IL-1 $\beta$ ) precursors to mature forms and cause pyroptosis (49-51). Our research results show that: after $24 \mathrm{~h}$ exposure to different concentrations of LPS, the mRNA and protein expression of NLRP3, ASC, and CASPASE-1 were increased in BEECs, and caspase- 1 protein cleavage could be observed, indicating that LPS can induce BEEC pyroptosis through the NLRP3 classical inflammasome pathway.

The non-classical inflammasome pathway is also called the caspase-1-independent inflammasome pathway because the cleavage of GSDMD is not by caspase-1, but via caspase-4/5/ 11 , an intracellular LPS receptor. It was previously thought that LPS could only stimulate TLR4 receptors outside the cell and cause inflammation through the NF- $\mathrm{KB}$ signaling pathway or the classical inflammasome signaling pathway. However, recent studies have found a direct receptor caspase-4/5/11 for LPS in the cell. Its expression depends on TLR $2 / 3 / 4$ receptor activation, but its activation must involve the participation of intracellular LPS. The activation of caspase-4/5/11 is also different from the self-cleavage of caspase-1, where oligomerization occurs. Studies have shown that the activation of caspase-4/5/11 is dependent on its CARD domain and the hexadecyl lipid A in LPS (52-55), and a research on primary endometrial epithelial and stromal fibroblast cells of bovine have told that: NLRP3 and caspase-4 mediated IL- $1 \beta$ production in a non-canonical inflammasome way (56). Our results show that after BEEC exposure $24 \mathrm{~h}$ with different concentrations of LPS, the mRNA and protein expressions of caspase- 4 are increased, indicating that LPS could induce BEECs pyroptosis through the non-classical inflammasome pathway.

This study shows that LPS could cause BEEC inflammation and mediate pyroptosis through not only NLRP3 classical but also nonclassical inflammasome pathways. LPS could be transferred into the cytoplasm via the bacterial outer membrane vesicles (OMV) or the high-mobility group box 1 (HMGB1) protein and receptor for advanced glycation end products (RAGE) complexes to trigger caspase-4/5/11 (57), further research could be required to evaluate the molecular mechanism through which microorganisms penetrate

\section{REFERENCES}

1. Kelly P, Barry-Reidy A, Brewer A, Meade KG, O'Farrelly C. Improved Filtration Method to Isolate Pure Populations of Primary Bovine Endometrial Epithelial and Stromal Cells for Immunological Studies. Vet Res Commun (2020) 44:29-39. doi: 10.1007/s11259-020-09770-3

2. Gilbert RO. Symposium Review: Mechanisms of Disruption of Fertility by Infectious Diseases of the Reproductive Tract. J Dairy Sci (2019) 102:3754-65. doi: 10.3168/jds.2018-15602

3. Fu Y, Liu B, Feng X, Liu Z, Liang D, Li F, et al. Lipopolysaccharide Increases Toll-like Receptor 4 and Downstream Toll-Like Receptor Signaling Molecules Expression in Bovine Endometrial Epithelial Cells. Vet Immunol Immunopathol (2013) 151:20-7. doi: 10.1016/j.vetimm.2012.09.039

4. Zhang C, Wang L, Li T, Mao W, Liu B, Cao J. Ep2/4 Receptors Promote the Synthesis of PGE2 Increasing Tissue Damage in Bovine Endometrial Explants Induced by Escherichia Coli. J Pharmacol Exp Ther (2020) 372:175-84. doi: 10.1124/jpet.119.262444 the cell receptors and cause damage to the cell's cytoplasm leading to pyroptosis.

\section{DATA AVAILABILITY STATEMENT}

The original contributions presented in the study are included in the article/Supplementary Material. Further inquiries can be directed to the corresponding author.

\section{AUTHOR CONTRIBUTIONS}

MY analyzed the experiment data and drafted the manuscript. LJ, SX,YJ, JW, and BI helped to conceptualized the work and collected data. AO, WY, WH, DZ, and YY participated in the design of the study and critically reviewed the manuscript. WY and YT participated in the design of the study and managed the project. All authors contributed to the article and approved the submitted version.

\section{FUNDING}

This research was funded by the National Key R\&D Program of China (No.2017YFD0502201), the Science and Technology Innovation Project (No. CAAS-ASTIP-2014-LIHPS-03), and the Key Research and Development Plan of Gansu province (20YF8NA029), and the Talent innovation and entrepreneurship project of Lanzhou city (2018-RC-91). The funding agencies had no role in the study design, data collection, analysis, or preparation or decision to publish the manuscript.

\section{SUPPLEMENTARY MATERIAL}

The Supplementary Material for this article can be found online at: https://www.frontiersin.org/articles/10.3389/fimmu.2021.676088/ full\#supplementary-material

5. Madoz LV, Giuliodori MJ, Migliorisi AL, Jaureguiberry M, de la Sota RL. Endometrial Cytology, Biopsy, and Bacteriology for the Diagnosis of Subclinical Endometritis in Grazing Dairy Cows. J Dairy Sci (2014) 97:195201. doi: $10.3168 /$ jds.2013-6836

6. Sheldon IM, Williams EJ, Miller AN, Nash DM, Herath S. Uterine Diseases in Cattle After Parturition. Vet J (2008) 176:115-21. doi: 10.1016/j.tvjl.2007.12.031

7. Madoz LV, Giuliodori MJ, Jaureguiberry M, Plöntzke J, Drillich M, de la Sota RL. The Relationship Between Endometrial Cytology During Estrous Cycle and Cutoff Points for the Diagnosis of Subclinical Endometritis in Grazing Dairy Cows. J Dairy Sci (2013) 96:4333-9. doi: 10.3168/jds.2012-6269

8. Sheldon IM, Price SB, Cronin J, Gilbert RO, Gadsby JE. Mechanisms of Infertility Associated With Clinical and Subclinical Endometritis in High Producing Dairy Cattle. Reprod Domest Anim (2009) 44:1-9. doi: 10.1111/j.1439-0531.2009.01465.x

9. Runciman DJ, Anderson GA, Malmo J. Comparison of Two Methods of Detecting Purulent Vaginal Discharge in Postpartum Dairy Cows and Effect of Intrauterine Cephapirin on Reproductive Performance. Aust Vet J (2009) 87:369-78. doi: 10.1111/j.1751-0813.2009.00469.x 
10. Dubuc J, Duffield TF, Leslie KE, Walton JS, LeBlanc SJ. Risk Factors for Postpartum Uterine Diseases in Dairy Cows. J Dairy Sci (2010) 93:5764-71. doi: $10.3168 /$ jds.2010-3429

11. Loyi T, Kumar H, Nandi S, Patra MK. Expression of Pathogen Recognition Receptors and Pro-Inflammatory Cytokine Transcripts in Clinical and SubClinical Endometritis Cows. Anim Biotechnol (2015) 26:194-200. doi: 10.1080/10495398.2014.987389

12. Esposito G, Irons PC, Webb EC, Chapwanya A. Interactions Between Negative Energy Balance, Metabolic Diseases, Uterine Health and Immune Response in Transition Dairy Cows. Anim Reprod Sci (2014) 144:60-71. doi: 10.1016/j.anireprosci.2013.11.007

13. Plöntzke J, Madoz LV, De la Sota RL, Drillich M, Heuwieser W. Subclinical Endometritis and Its Impact on Reproductive Performance in Grazing Dairy Cattle in Argentina. Anim Reprod Sci (2010) 122:52-7. doi: 10.1016/j.anireprosci. 2010.07.006

14. Carneiro LC, Cronin JG, Sheldon IM. Mechanisms Linking Bacterial Infections of the Bovine Endometrium to Disease and Infertility. Reprod Biol (2016) 16:1-7. doi: 10.1016/j.repbio.2015.12.002

15. Bicalho ML, Machado VS, Oikonomou G, Gilbert RO, Bicalho RC. Association Between Virulence Factors of Escherichia Coli, Fusobacterium Necrophorum, and Arcanobacterium Pyogenes and Uterine Diseases of Dairy Cows. Vet Microbiol (2012) 157:125-31. doi: 10.1016/j.vetmic.2011.11.034

16. Sheldon IM, Rycroft AN, Dogan B, Craven M, Bromfield JJ, Chandler A, et al. Specific Strains of Escherichia Coli Are Pathogenic for the Endometrium of Cattle and Cause Pelvic Inflammatory Disease in Cattle and Mice. PloS One (2010) 5:e9192. doi: 10.1371/journal.pone.0009192

17. Zhang H, Wu ZM, Yang YP, Shaukat A, Yang J, Guo YF, et al. Catalpol Ameliorates LPS-Induced Endometritis by Inhibiting Inflammation and TLR4/NF-kb Signaling. J Zhejiang Univ Sci B (2019) 20:816-27. doi: 10.1631/ jzus.B1900071

18. Jhamat N, Niazi A, Guo Y, Chanrot M, Ivanova E, Kelsey G, et al. LPSTreatment of Bovine Endometrial Epithelial Cells Causes Differential DNA Methylation of Genes Associated With Inflammation and Endometrial Function. BMC Genomics (2020) 21:385. doi: 10.1186/s12864-020-06777-7

19. Zhao G, Jiang K, Yang Y, Zhang T, Wu H, Shaukat A, et al. The Potential Therapeutic Role of miR-223 in Bovine Endometritis by Targeting the NLRP3 Inflammasome. Front Immunol (2018) 9:1916. doi: 10.3389/fimmu.2018.01916

20. Cookson BT, Brennan MA. Pro-Inflammatory Programmed Cell Death. Trends Microbiol (2001) 9:113-4. doi: 10.1016/s0966-842x(00)01936-3

21. Jorgensen I, Miao EA. Pyroptotic Cell Death Defends Against Intracellular Pathogens. Immunol Rev (2015) 265(1):130-42. doi: 10.1111/imr.12287

22. Man SM, Karki R, Kanneganti TD. Molecular Mechanisms and Functions of Pyroptosis, Inflammatory Caspases and Inflammasomes in Infectious Diseases. Immunol Rev (2017) 277(1):61-75. doi: 10.1111/imr.12534

23. Shi J, Zhao Y, Wang K, Shi X, Wang Y, Huang H, et al. Cleavage of GSDMD by Inflammatory Caspases Determines Pyroptotic Cell Death. Nature (2015) 526:660-5. doi: 10.1038/nature15514

24. Kayagaki N, Stowe IB, Lee BL, O’Rourke K, Anderson K, Warming S, et al. Caspase-11 Cleaves Gasdermin D for Non-Canonical Inflammasome Signalling. Nature (2015) 526:666-71. doi: 10.1038/nature15541

25. Chen X, He WT, Hu L, Li J, Fang Y, Wang X, et al. Pyroptosis Is Driven by Non-Selective Gasdermin-D Pore and Its Morphology Is Different From MLKL Channel-Mediated Necroptosis. Cell Res (2016) 26:1007-20. doi: $10.1038 /$ cr.2016.100

26. Lightfield KL, Persson J, Brubaker SW, Witte CE, von Moltke J, Dunipace EA, et al. Critical Function for Naip5 in Inflammasome Activation by a Conserved Carboxy-Terminal Domain of Flagellin. Nat Immunol (2008) 9:1171-8. doi: $10.1038 /$ ni.1646

27. Ge X, Li W, Huang S, Yin Z, Xu X, Chen F, et al. The Pathological Role of NLRs and AIM2 Inflammasome-Mediated Pyroptosis in Damaged BloodBrain Barrier After Traumatic Brain Injury. Brain Res (2018) 1697:10-20. doi: 10.1016/j.brainres.2018.06.008

28. Rathinam VA, Vanaja SK, Fitzgerald KA. Regulation of Inflammasome Signaling. Nat Immunol (2012) 13:333-42. doi: 10.1038/ni.2237

29. He WT, Wan H, Hu L, Chen P, Wang X, Huang Z, et al. Gasdermin D Is an Executor of Pyroptosis and Required for Interleukin-1 $\beta$ Secretion. Cell Res (2015) 25:1285-98. doi: 10.1038/cr.2015.139
30. Jin C, Flavell RA. Molecular Mechanism of NLRP3 Inflammasome Activation. J Clin Immunol (2010) 30:628-31. doi: 10.1007/s10875-010-9440-3

31. Shi J, Zhao Y, Wang Y, Gao W, Ding J, Li P, et al. Inflammatory Caspases Are Innate Immune Receptors for Intracellular LPS. Nature (2014) 514:187-92. doi: 10.1038/nature13683

32. Kayagaki N, Warming S, Lamkanfi M, Vande Walle L, Louie S, Dong J, et al. Non-Canonical Inflammasome Activation Targets Caspase-11. Nature (2011) 479:117-21. doi: 10.1038/nature10558

33. Horng T, Hotamisligil GS. Linking the Inflammasome to Obesity-Related Disease. Nat Med (2011) 17:164-5. doi: 10.1038/nm0211-164

34. Gombault A, Baron L, Couillin I. ATP Release and Purinergic Signaling in NLRP3 Inflammasome Activation. Front Immunol (2013) 3:414. doi: 10.3389/ fimmu.2012.00414

35. Li Y, Wang D, Wu X, He B, Cheng Z, Szenci O, et al. Decreasing of S100A4 in Bovine Endometritis In Vivo and In Vitro. Theriogenology (2020) 153:68-73. doi: 10.1016/j.theriogenology.2020.05.015

36. Arocho A, Chen B, Ladanyi M, Pan Q. Validation of the 2-Delta Delta Ct Calculation as an Alternate Method of Data Analysis for Quantitative PCR of BCR-ABL P210 Transcripts. Diagn Mol Pathol (2006) 15:56-61. doi: 10.1097/ 00019606-200603000-00009

37. Sheldon IM, Cronin JG, Pospiech M, Turner ML. Symposium Review: Mechanisms Linking Metabolic Stress With Innate Immunity in the Endometrium. J Dairy Sci (2018) 101:3655-64. doi: 10.3168/jds.2017-13135

38. Sheldon IM, Cronin JG, Bromfield JJ. Tolerance and Innate Immunity Shape the Development of Postpartum Uterine Disease and the Impact of Endometritis in Dairy Cattle. Annu Rev Anim Biosci (2019) 7:361-84. doi: 10.1146/annurev-animal-020518-115227

39. Ibrahim M, Peter S, Wagener K, Drillich M, Ehling-Schulz M, Einspanier R, et al. Bovine Endometrial Epithelial Cells Scale Their Pro-Inflammatory Response In Vitro to Pathogenic Trueperella Pyogenes Isolated From the Bovine Uterus in a Strain-Specific Manner. Front Cell Infect Microbiol (2017) 7:264. doi: 10.3389/fcimb.2017.00264

40. Esposito E, Cuzzocrea S. TNF-Alpha as a Therapeutic Target in Inflammatory Diseases, Ischemia-Reperfusion Injury and Trauma. Curr Med Chem (2009) 16:3152-67. doi: 10.2174/092986709788803024

41. Kim JA, Ko JH, Ko AY, Lee HJ, Kim MK, Wee WR, et al. TSG-6 Protects Corneal Endothelium From Transcorneal Cryoinjury in Rabbits. Invest Ophthalmol Vis Sci (2014) 55:4905-12. doi: 10.1167/iovs.14-14538

42. Ferrari E, Capucciati A, Prada I, Zucca FA, D’Arrigo G, Pontiroli D, et al. Synthesis, Structure Characterization, and Evaluation in Microglia Cultures of Neuromelanin Analogues Suitable for Modeling Parkinson's Disease. ACS Chem Neurosci (2017) 8:501-12. doi: 10.1021/acschemneuro.6b00231

43. Yang R, Masters AR, Fortner KA, Champagne DP, Yanguas-Casás N, Silberger DJ, et al. IL-6 Promotes the Differentiation of a Subset of Naive CD8+ T Cells Into IL-21-Producing B Helper CD8+ T Cells. J Exp Med (2016) 213:2281-91. doi: 10.1084/jem.20160417

44. Wu D, Pan P, Su X, Zhang L, Qin Q, Tan H, et al. Interferon Regulatory Factor-1 Mediates Alveolar Macrophage Pyroptosis During Lps-Induced Acute Lung Injury in Mice. Shock (2016) 46:329-38. doi: 10.1097/SHK

45. Wu Y, Sun Y, Zhang Z, Chen J, Dong G. Effects of Peptidoglycan, Lipoteichoic Acid and Lipopolysaccharide on Inflammation, Proliferation and Milk Fat Synthesis in Bovine Mammary Epithelial Cells. Toxins (Basel) (2020) 12:497. doi: $10.3390 /$ toxins 12080497

46. Wu H, Zhao G, Jiang K, Li C, Qiu C, Deng G. Engeletin Alleviates Lipopolysaccharide-Induced Endometritis in Mice by Inhibiting TLR4Mediated NF-kb Activation. J Agric Food Chem (2016) 64:6171-8. doi: 10.1021/acs.jafc.6b02304

47. Liu YH, Chang YC, Chen LK, Su PA, Ko WC, Tsai YS, et al. The ATP-P2X7 Signaling Axis Is an Essential Sentinel for Intracellular Clostridium Difficile Pathogen-Induced Inflammasome Activation. Front Cell Infect Microbiol (2018) 8:84. doi: 10.3389/fcimb.2018.00084

48. Zhang D, Zhou J, Ye LC, Li J, Wu Z, Li Y, et al. Autophagy Maintains the Integrity of Endothelial Barrier in LPS-induced Lung Injury. J Cell Physiol (2018) 233:688-98. doi: $10.1002 /$ jcp.25928

49. Vanaja SK, Rathinam VA, Fitzgerald KA. Mechanisms of Inflammasome Activation: Recent Advances and Novel Insights. Trends Cell Biol (2015) 25:308-15. doi: 10.1016/j.tcb.2014.12.009 
50. Schroder K, Tschopp J. The Inflammasomes. Cell (2010) 140:821-32. doi: 10.1016/j.cell.2010.01.040

51. Von Moltke J, Ayres JS, Kofoed EM, Chavarría-Smith J, Vance RE. Recognition of Bacteria by Inflammasomes. Annu Rev Immunol (2013) 31:73-106. doi: 10.1146/annurev-immunol-032712-095944

52. Rathinam VA, Vanaja SK, Waggoner L, Sokolovska A, Becker C, Stuart LM, et al. TRIF Licenses Caspase-11-Dependent NLRP3 Inflammasome Activation by Gram-Negative Bacteria. Cell (2012) 150:606-19. doi: 10.1016/j.cell. 2012.07.007

53. Aachoui Y, Kajiwara Y, Leaf IA, Mao D, Ting JP, Coers J, et al. Canonical Inflammasomes Drive Ifn- $\gamma$ to Prime Caspase-11 in Defense Against a Cytosol-Invasive Bacterium. Cell Host Microbe (2015) 18:320-32. doi: 10.1016/ j.chom.2015.07.016

54. Broz P, Ruby T, Belhocine K, Bouley DM, Kayagaki N, Dixit VM, et al. Caspase-11 Increases Susceptibility to Salmonella Infection in the Absence of Caspase-1. Nature (2012) 490:288-91. doi: 10.1038/nature11419

55. Hagar JA, Powell DA, Aachoui Y, Ernst RK, Miao EA. Cytoplasmic LPS Activates Caspase-11: Implications in TLR4-Independent Endotoxic Shock. Science (2013) 34:1250-3. doi: 10.1126/science.1240988
56. Kelly P, Meade KG, O'Farrelly C. Non-Canonical Inflammasome-Mediated IL-1 $\beta$ Production by Primary Endometrial Epithelial and Stromal Fibroblast Cells is NLRP3 and Caspase-4 Dependent. Front Immunol (2019) 10:102. doi: 10.3389/fimmu.2019.00102

57. Matikainen S, Nyman TA, Cypryk W. Function and Regulation of Noncanonical Caspase-4/5/11 Inflammasome. J Immunol (2020) 204:3063-69. doi: 10.4049/jimmunol.2000373

Conflict of Interest: The authors declare that the research was conducted in the absence of any commercial or financial relationships that could be construed as a potential conflict of interest.

Copyright (c) $2021 \mathrm{Ma}$, Li, Shen, Oladejo, Yang, Jiang, Imam, Wu, Ding, Yang, Wang and Yan. This is an open-access article distributed under the terms of the Creative Commons Attribution License (CC BY). The use, distribution or reproduction in other forums is permitted, provided the original author(s) and the copyright owner(s) are credited and that the original publication in this journal is cited, in accordance with accepted academic practice. No use, distribution or reproduction is permitted which does not comply with these terms. 